\title{
The Economic and Environmental Benefits of Solar Energy in the Agricultural Sector: The Case of Morocco
}

\author{
Roberto Ariel Telleria Juárez ${ }^{1 *}$, Hassane Serghini Idrissi ${ }^{2}$, Ampaitepin Singhabhandhu $^{3}$, Aden Aw-Hassan ${ }^{4}$ \\ Abdelali Laamari $^{5}$ \\ ${ }^{1}$ Food and Agriculture Organization of the United Nations (FAO) \\ Rome - Italy \\ ${ }^{2}$ University of Hassan II \\ Rabat - Morocco \\ ${ }^{3}$ Arab Center for Consulting and Training Services (ACCTS) \\ Amman - Jordan \\ ${ }^{4}$ Consultative Group on International Agricultural Research (CGIAR) \\ Canada \\ ${ }^{5}$ Institut National de la Recherche Agronomique (INRA) \\ Rabat - Morocco \\ *Corresponding author's email: roberto.telleriajuarez [AT] fao.org
}

\begin{abstract}
The main purpose of this research was to analyse the potential of solar panels to replace both LPG (butane gas cylinders) and diesel currently used in Morocco for agricultural irrigation. A swap would help Morocco to conserve the environment by using cleaner energy, as well as moving towards meeting Morocco's emission targets. For this purpose, we surveyed 112 farmers in two Moroccan regions, Sidi El Aidi and Fquih Ben Salah. We found that pumping one cubic meter of groundwater with solar energy was in average 33.3\% cheaper in Sidi El Aidi, and 60.6\% cheaper in Fquih Ben Salah than pumping using LPG.

Net present value estimates suggest that investing in solar panels is profitable. Environmental analysis suggested that switching from LPG or diesel to solar energy would save the equivalent amount of energy used by 13 25 million 60-W electric bulbs per year. The government, farmers and the environment would gain by replacing LPG with solar energy. However, once solar panels are installed, pumping cost is virtually zero. Farmers may be tempted to overuse irrigation water, and consequently accelerate the depletion of groundwater. Implementing groundwater regulations to control the amount of groundwater pumped should precede any government program intended to promote solar energy.
\end{abstract}

Keywords--- Solar energy; Groundwater; Emissions; Subsidy, Morocco

\section{INTRODUCTION}

For many years Moroccan farmers have used diesel to pump irrigation water. As the official price of diesel increased in Morocco throughout the last decade, while the price of liquefied petroleum gas (LPG) ${ }^{1}$ remained unchanged and subsidized (IMF, 2017), farmers started switching from diesel to LPG for pumping water and irrigating crops (IISD, 2019). The main reason for this change is that LPG for all Moroccan households (urban or rural) is subsidized to enable all people in the country (particularly low-income households) to afford energy services and to alleviate energy poverty. In 2019 the price of a 12-kg bottle of cooking gas was around US\$ 8.6 or about 84 dirhams (DH), but Moroccans pay just $48 \%$ (40 DH) of that amount as the government fixed a retail price of US\$ 4.4 (40 DH) per bottle (MEFRA, 2020). From the government perspective, both the increase in demand for subsidized LPG and high dependence on imported LPG have turned the LPG subsidy into a very heavy financial burden. In 2018, about $90 \%$ of the country's LPG requirements came from the European Union (36\%), the USA (29\%) and Algeria (24\%) (MEFRA, 2020; Hespress, 2019), and hence highly dependent on international price fluctuations.

\footnotetext{
${ }^{1}$ Liquefied petroleum gas (LPG), also referred to as simply bottled butane gas is used primarily by Moroccan households for cocking. The government subsidizes LPG to enhance access to energy, and partly to stop rural households from burning biomass at home. Farmers use LPG for pumping groundwater and irrigate crops.
} 
Although there is no official estimate of LPG use in irrigation, field observations throughout Morocco suggest that ever more farmers are substituting diesel with LPG. As shown in Section 3, our survey found that $87 \%$ of all surveyed farmers (112) were already using LPG as their primary energy source for pumping irrigation groundwater. This could be a potential major issue to society and the environment, as subsidized energy results in excessive water pumping and inexorable reductions in aquifer levels (IMF, 2014), and include environmental damage through increased emissions of greenhouse gases and other air pollutants.

Currently there is a debate in Morocco around the implementation of subsidies for investment in solar energy and the withdrawal of subsidies for LPG. In fact, the Ministry of Energy, Mines, Water and Environment requested that the use of solar panels as an alternative energy source to LPG be studied as an agricultural and water policy measure to cope with several issues: (i) shrinking government resources to subsidize LPG; (ii) farmers' needs to secure energy for irrigation purposes; and (iii) concerns for environmental aspects (Energie \& Stratégie, 2018). The findings of this paper intent to contribute to this debate by analysing the use of solar panels as an alternative to LPG and as a policy option to provide farmers with their own power system to: (i) reduce farmers' expenditure on energy, (ii) reduce government expenditure, and (iii) reduce the emissions of petroleum-based pollutants.

Following this introduction, the paper is organized as follows: Section 2 discusses our survey sample and study sites. Section 3 presents study results including: (i) energy costs for pumping groundwater using LPG and diesel systems; (ii) scenarios simulating spreading out of LPG use in the country and its impact on the government's financial subsidy; (iii) solar energy costs comparing LPG and solar system; (iv) estimates on net present value (NPV); and (v) environmental analysis consisting of comparing carbon dioxide $\left(\mathrm{CO}_{2}\right)$ emissions from LPG and diesel systems, and energy saving from solar system use. Finally, Section 4 presents conclusions and recommendations emerging from this study.

\section{SITES AND SAMPLING}

To analyse the feasibility of solar energy as the primary power-source for irrigation, the main objective of this study, we surveyed farmers from two Moroccan rural areas: Sidi El Aidi (a small rural commune in Settat Province of the Chaouia-Ouardigha region) and Fquih Ben Salah (a rural commune of Béni Mellal-Khénifra region). We surveyed 112 farmers in total, representing a good mixture of practices in both regions. The survey took place between January and March 2014. The reason for using a 2014 survey was to assess how the LPG subsidy would be affected if farmers had gradually adopted the use of solar systems for agriculture.

These two regions were selected as LPG and diesel are commonly used to pump water from private wells to irrigate crops. Farmers surveyed from Sidi El Aidi belonged to a farmer cooperative with 255 members representing 10 villages around Sidi El Aidi. In total 43 farmers were randomly selected, representing $20 \%$ of the total members of the cooperative. Farmers surveyed in Fquih Ben Salah belonged to a water users association with 550 members - of these, 69 farmers $(13.7 \%)$ were randomly selected.

Before the survey took place, we piloted the questionnaire on a subset of the farmer cooperative in Sidi El Aidi. Then, we trained ten enumerators through a three-day field training, where they learned the objectives of the study and the technical content of each section of the questionnaire. Each enumerator was provided with the enumerator's guide that contained instructions on how to complete the survey, including how to check for internal consistency of the answers. The survey streamlined 14 discussion questions around six areas: farm characteristics, irrigation facilities, water storage, cost of pumping, energy used by the household, and potential use of solar energy for irrigation. The survey consisted of analytical questions that generated baseline information, and clarifying questions that provided more indepth data. All enumerators were recruited locally.

\section{STUDY RESULTS}

We found that the farmers from Sidi El Aidi and Fquih Ben Salah shared several features: all had at least one irrigated plot, they owned at least one well, most of them rented tractor services, all had a diversified production system, and all had irrigation patterns with some potential for adopting solar energy systems.

\subsection{Energy costs for pumping groundwater using LPG and diesel systems}

No sampled farmer in Sidi El Aidi used diesel as the primary energy source to pump groundwater to irrigate crops as all 43 farmers had converted to LPG (Table 1)². In Fquih Ben Salah, 77\% (53) of sampled farmers used LPG to irrigate crops, while $23 \%$ (16) used diesel, as their primary source of energy to pump groundwater. Thus, in average $86 \%$

2 The survey revealed that a decade ago producers in Sidi El Aidi were using diesel pumps for irrigating crops. When the government started subsidizing LPG, it became cheaper and as result many farmers in the community switched to LPG pumps. This would explain that the survey was unable to find farmers in Sidi El Aidi extracting groundwater using diesel pumps. 
(96) of the 112 sampled farmers used LPG as their primary source of energy to pump groundwater and irrigate their crops. Farmers pointed out that as time passes progressive substitution from diesel to LPG takes place. However, they do not completely get rid of the diesel system, but keep it in case of need, such as unavailability of LPG or a faulty engine that would still work with diesel.

The energy cost for pumping water differs across wells in both regions. In Sidi El Aidi the average cost of pumping using LPG $0.3 \mathrm{DH} / \mathrm{m}^{3}$. In Fquih Ben Salah the average cost of pumping using LPG was $0.33 \mathrm{DH} / \mathrm{m}^{3}$, while in the case of diesel the average cost of pumping water was $0.67 \mathrm{DH} / \mathrm{m}^{3}$. Thus, extracting water from wells using diesel pumps in Fquih Ben Salah cost double the cost of pumping using LPG.

Table 1. Energy cost of pumping groundwater

\begin{tabular}{l|c|c|c}
\hline \multirow{2}{*}{ Cost levels } & Sidi El Aidi & \multicolumn{2}{|c}{ Fquih Ben Salah } \\
\cline { 2 - 4 } & LPG (\%) & LPG (\%) & Diesel (\%) \\
\hline Average cost (DH/m3) & 0.30 & 0.33 & 0.67 \\
\hline Total quantity of wells (\%) & 100 & 100 & 100 \\
\hline \multirow{2}{*}{ Number of observations (112) } & \multirow{2}{*}{69} & 16 \\
\cline { 2 - 4 }
\end{tabular}

Source: Own elaboration based on solar panel survey.

Consequently, in these two regions switching from diesel to LPG has primarily been a matter of cost. The average LPG cost for pumping water was very similar $\left(0.30\right.$ and $0.33 \mathrm{DH} / \mathrm{m}^{3}$ in Sidi El Aidi and Fquih Ben Salah, respectively - a $10 \%$ difference), showing congruence in production costs across regions. The huge difference in pumping cost (average $0.315 \mathrm{DH} / \mathrm{m}^{3}$ for LPG and $0.67 \mathrm{DH} / \mathrm{m}^{3}$ for diesel) explains the economic rationale behind all farmers in Sidi El Aidi converting their pumps from diesel to LPG, while most farmers in Fquih Ben Salah were following in the same direction.

\subsection{Scenarios simulating spreading out of LPG use}

This trend of replacement of diesel by LPG has been reinforced by increases in diesel prices in Morocco, which started in 2012 when the government increased it by 14\%, and then by another $8.5 \%$ in 2013 (Albertin, 2014). Towards the end of 2014, the government eliminated the subsidy to diesel (World Bank, 2019), which further encouraged farmers to progressively shift from diesel to LPG. Consequently, the demand for LPG has been increasing (IISD, 2018), further raising the financial burden of LPG subsidy for the Moroccan government. To estimate this increase in the financial LPG subsidy provided by the government, we assumed four scenarios that simulated increased use of LPG to irrigate private land in Morocco: Scenarios 1-4 of 30, 50, 75, and 100\% of private irrigation using LPG, respectively.

Scenario 1 establishes that $30 \%$ of all private agricultural lands in Morocco equipped with irrigation facilities use LPG to pump groundwater. Scenario 2 assumes that $50 \%$ of all private agricultural lands equipped with irrigation facilities use LPG to pump groundwater (analogous reading applies to the other two scenarios). To test these scenarios, we estimated the following variables: (i) The average quantity (in litres) of water pumped with one bottle of LPG; (ii) The level of subsidy per kg of LPG, which in 2019 was $3.7 \mathrm{DH} / \mathrm{kg}$ or $44 \mathrm{DH} / \mathrm{bottle}^{3}$ (MEFRA, 2020); and (iii) The quantity of water that will be pumped using LPG as specified in each scenario above. We estimated that the average amount of water pumped with a single bottle of LPG was 140 and $124 \mathrm{~m}^{3}$ in Sidi El Aidi and Fquih Ben Salah, respectively (Table 2). Most farmers (51.2\%) in Sidi El Aidi and 36.4\% in Fquih Ben Salah used one bottle to abstract between 100 and $149 \mathrm{~m}^{3}$ of groundwater. Variations in the amount of groundwater pumped per bottle of LPG mainly depend on well depth (a deeper water table requires more energy).

Table 2. Groundwater abstraction per LPG bottle by region and farmer

\begin{tabular}{l|c|c}
\hline $\begin{array}{l}\text { Quantity of groundwater }\left(\mathbf{m}^{\mathbf{3}}\right) \text { that can be } \\
\text { abstracted with one bottle of LPG }\end{array}$ & $\begin{array}{c}\text { \% of farmers in } \\
\text { Sidi El Aidi }\end{array}$ & $\begin{array}{c}\text { \% of farmers in } \\
\text { Fquih Ben Salah }\end{array}$ \\
\hline Less than $100 \mathrm{~m}^{3} /$ bottle & 14.0 & 21.8 \\
\hline Between 100 and $149 \mathrm{~m}^{3} /$ bottle & 51.2 & 36.4 \\
\hline Between 150 and $199 \mathrm{~m}^{3} /$ bottle & 27.9 & 29.1 \\
\hline $200 \mathrm{~m}^{3} /$ bottle or more & 7.0 & 12.7 \\
\hline Total & 100 & 100 \\
\hline Average abstraction $\left(\mathbf{m}^{\mathbf{3}} /\right.$ bottle of $\left.\mathbf{L P G}\right)$ & $\mathbf{1 4 0}$ & $\mathbf{1 2 4}$ \\
\hline
\end{tabular}

Source: Own elaboration based on solar panel survey.

\footnotetext{
${ }^{3}$ each bottle weights $12 \mathrm{~kg}$.
} 
In Morocco it is estimated that private irrigated areas cover 441,430 ha, and use four billion $\mathrm{m}^{3}$ of groundwater annually (FAO, 2015). When accounting for increases in groundwater abstraction as in the above scenarios, and by estimating the number of LPG bottles needed to meet these increases, an estimate of the financial resources needed to cover more demand for LGP was obtained (Table 3). We estimated that if irrigated areas (that use LPG for pumping) increased by $30 \%$ (Scenario 1), the financial burden would be around 0.4 billion DH (about US\$ 41.3 million) per yeara $3.3 \%$ increase on the 12.1 billion DH (about US\$ 1,249 million) that the government provided in 2018 to subsidize LPG in Morocco (MEFRA, 2020). If all current irrigated areas used LPG in Morocco (Scenario 4), then four billion $\mathrm{m}^{3}$ would be needed. Along with increased LPG demand, the associated subsidy would grow to 1.33 billion DH (about US\$ 138 million) annually, representing $11.0 \%$ of the 2018 subsidy to LPG in Morocco.

Table 3. Impact of shifting from diesel to LPG

\begin{tabular}{l|c|c|c}
\hline $\begin{array}{c}\text { Scenario: Percentage of } \\
\text { private irrigated areas } \\
\text { using LPG }\end{array}$ & $\begin{array}{c}\text { Increased amount of } \\
\text { groundwater pumped using } \\
\text { LPG (billion } \mathbf{~ m}^{\mathbf{3}} \text { ) }\end{array}$ & $\begin{array}{c}\text { Increase in LPG } \\
\text { subsidy (billion DH) }\end{array}$ & $\begin{array}{c}\text { Percentage of } \\
\text { increase respect to } \\
\text { 2018 LPG subsidy }\end{array}$ \\
\hline Scenario 1: 30\% & 1.2 & 0.4 & 3.3 \\
\hline Scenario 2: $50 \%$ & 2.0 & 0.67 & 5.5 \\
\hline Scenario 3: $75 \%$ & 3.0 & 1.0 & 8.3 \\
\hline Scenario 4: $100 \%$ & 4.0 & 1.33 & 11.0 \\
\hline
\end{tabular}

Source: Own elaboration based on data from FAO (2015) and MEFRA (2020).

\subsection{Solar energy investments and comparisons between LPG and solar system pumping costs}

One possibility to reduce the use of LPG is to promote the use of solar energy for pumping groundwater. To evaluate this possibility, we compared the costs of pumping groundwater using both LPG and solar systems. As our survey did not find any farmer using solar energy for irrigation purposes in Sidi El Aidi and Fquih Ben Salah, no information on solar system costs was found for our study sites. Therefore, a solar energy dealer in Rabat was interviewed for information on solar energy costs. This dealer has installed a number of solar energy systems throughout the country, and was able to provide data on installation costs (including depreciation and capacity of groundwater abstraction) for nine of them (Table 4). Data on installation costs of solar systems suggest that the deeper the well the higher the total investment (correlation coefficient $r=0.78$ ). However, as investment increases, the quantity of groundwater that can be pumped also increases $(\mathrm{r}=0.59)$.

Table 4. Solar energy installation system cost

\begin{tabular}{c|c|c|c|c}
\hline Case & $\begin{array}{c}\text { Well depth } \\
(\mathrm{m})\end{array}$ & $\begin{array}{c}\text { Groundwater } \\
\text { abstraction }\left(\mathrm{m}^{3} / \text { day }\right)\end{array}$ & $\begin{array}{c}\text { Total cost of the } \\
\text { investment }(\mathrm{DH})\end{array}$ & $\begin{array}{c}\text { Annual depreciation of the } \\
\text { whole investment }(\mathrm{DH})\end{array}$ \\
\hline 1 & 30 & 22 & 25,068 & 2,062 \\
\hline 2 & 200 & 140 & 567,312 & 34,492 \\
\hline 3 & 49 & 340 & 293,040 & 18,622 \\
\hline 4 & 56 & 65 & 89,296 & 5,982 \\
\hline 5 & 80 & 100 & 188,802 & 3,790 \\
\hline 6 & 30 & 50 & 49,760 & 5,982 \\
\hline 7 & 90 & 30 & 89,296 & 23,199 \\
\hline 8 & 120 & 153 & 358,017 & 18,600 \\
\hline 9 & 46 & 192 & 330,000 & $\mathbf{1 3 , 9 6 5}$ \\
\hline Average & $\mathbf{7 8}$ & $\mathbf{1 2 1}$ & $\mathbf{2 2 1 , 1 7 7}$ & \\
\hline
\end{tabular}

Source: Own elaboration based on data from interview with solar panel dealer in Rabat, Morocco.

To estimate the amount of groundwater that can potentially be abstracted using solar panels, we considered the depth of the well, the power of the solar system (reflected in the cost of the panels and electric motor), and the number of daylight hours per day (depending on the month). As we did not find information on daylight hours for the two regions under study, we used data on monthly average of sunny hours from the Casablanca area, which has similar weather conditions to the two study areas (Hassan Serghini, personal communication ${ }^{4}$ ). From this data, we estimated that

${ }^{4}$ Hassan Serghini is a Moroccan agricultural economist that has extensively worked in Casa Blanca, Sidi El Aidi and Fquih Ben Salah areas serving from 2001 to 2015 as Director of Programming and Economic Affairs at the Ministry of Agriculture and Fisheries (MAF) of Morocco, and more recently as free-lancer consultant. 
approximately 50 days per year are rainy and the rest (315) are sunny. The estimated average number of sunny hours per day is 8.7 (Table 5), while we estimated that the annual amount of sunshine per month is 2,464 hours.

Table 5. Average number of sunny hours per month

\begin{tabular}{l|c|c|c|c}
\hline Month & $\begin{array}{c}\text { Number of days } \\
\text { with rain (at least 1 } \\
\text { mm within 24 h) }\end{array}$ & $\begin{array}{c}\text { Average number } \\
\text { of sunny hours } \\
\text { per day }\end{array}$ & $\begin{array}{c}\text { Number of } \\
\text { hours of sun } \\
\text { per month }\end{array}$ & $\begin{array}{c}\text { Number of hours of } \\
\text { sun per month } \\
\text { reduced by 10\% }\end{array}$ \\
\hline January & 7 & 6 & 144 & 129.6 \\
\hline February & 6 & 7 & 154 & 138.6 \\
\hline March & 5 & 8 & 208 & 187.2 \\
\hline April & 6 & 10 & 280 & 194.4 \\
\hline May & 3 & 11 & 319 & 252.0 \\
\hline June & 1 & 11 & 310 & 287.1 \\
\hline July & 0 & 10 & 261 & 306.9 \\
\hline August & 1 & 9 & 208 & 234.0 \\
\hline September & 5 & 8 & 192 & 187.2 \\
\hline October & 6 & 8 & 105 & 172.8 \\
\hline November & 10 & 5 & $\mathbf{2 , 7 3 8}$ & 94.5 \\
\hline December & $\mathbf{5 0}$ & $\mathbf{8 . 7}$ & $\mathbf{2 , 4 6 4}$ \\
\hline Whole year & 6 & 9 & & \\
\hline
\end{tabular}

Note: The intensity of solar energy varies during the day. During early morning and late afternoon, solar energy loses power in pumping groundwater. To account for the reduced capability of capturing sunlight to pump water, we reduced the number of hours of sun per month by $10 \%$, bringing this estimate to a more conservative 2,464 hours per month.

Source: Own elaboration based on data from interview with solar panel dealer in Rabat, Morocco.

Taking into account the depth of wells, the power of solar systems, and the number of daylight hours per day, we estimated that for each of the nine cases the amount of groundwater that could be abstracted using solar panels was an average of 55,368 m³ year (Table 6). Notice that this calculation corresponds to the maximum quantity of groundwater that can be pumped using the solar system. The reason is that we wanted to estimate the worst-case scenario where solar panels are used at their maximum capacity in terms of groundwater abstraction. However, in reality the multi-cropping cycle suggests that there will be several sunny days where irrigation will not occur. Having estimated the annual quantity of groundwater pumped, we estimated the average cost of pumping one cubic meter of water per meter of depth as the relationship between average cost per cubic meter and well depth.

Table 6: Cost of pumping water by case

\begin{tabular}{|c|c|c|c|c|c|c|}
\hline Case & $\begin{array}{l}\text { Well } \\
\text { depth } \\
(\mathbf{m})\end{array}$ & $\begin{array}{l}\text { Annual quantity } \\
\text { of groundwater } \\
\text { pumped }\left(\mathbf{m}^{3}\right)\end{array}$ & $\begin{array}{l}\text { Annual quantity of } \\
\text { water pumped } \\
\text { according to well } \\
\text { depth }(\mathrm{m})\end{array}$ & $\begin{array}{c}\text { Annual } \\
\text { cost (DH) }\end{array}$ & $\begin{array}{l}\text { Average cost } \\
\text { of one } \mathbf{m}^{3} \\
\text { (DH) }\end{array}$ & $\begin{array}{l}\text { Cost of one } \mathrm{m}^{3} \\
\text { out of one meter } \\
\text { of depth }(\mathrm{DH})\end{array}$ \\
\hline 1 & 30 & 10,039 & 301,170 & 2,062 & 0.21 & 0.0068 \\
\hline 2 & 200 & 63,887 & $12,777,400$ & 34,492 & 0.54 & 0.0027 \\
\hline 3 & 49 & 155,153 & $7,602,497$ & 18,622 & 0.12 & 0.0024 \\
\hline 4 & 56 & 29,662 & $1,661,072$ & 5,982 & 0.20 & 0.0036 \\
\hline 5 & 80 & 45,633 & $3,650,640$ & 12,952 & 0.28 & 0.0035 \\
\hline 6 & 30 & 22,817 & 684,510 & 3,790 & 0.17 & 0.0055 \\
\hline 7 & 90 & 13,690 & $1,232,100$ & 5,982 & 0.44 & 0.0049 \\
\hline 8 & 120 & 69,819 & $8,378,280$ & 23,199 & 0.33 & 0.0028 \\
\hline 9 & 46 & 87,616 & $4,030,336$ & 18,600 & 0.21 & 0.0046 \\
\hline Average & 78 & 55,368 & $4,479,778$ & 13,965 & 0.28 & 0.0041 \\
\hline SD & 54 & 45,942 & $4,258,037$ & 10,744 & 0.14 & 0.0015 \\
\hline
\end{tabular}

Source: Own elaboration based on data from interview with solar panel dealer in Rabat, Morocco. 
We estimated that the cost of one cubic meter per one meter depth was $0.0041 \mathrm{DH}$ (last column in Table 6), and this tended to be higher for lesser depths (less than $50 \mathrm{~m}$ ) and lower for greater depths (more than $50 \mathrm{~m}$ ) (Figure 1). The reason for this is as follows: initially the cost of pumping is higher when the water table is deeper, but the real cost of pumping becomes cheaper because large solar systems can pump larger quantities of groundwater and so make the cost of pumping per cubic meter cheaper in deep wells.

Figure 1. Cost of one cubic meter per one meter depth (DH)

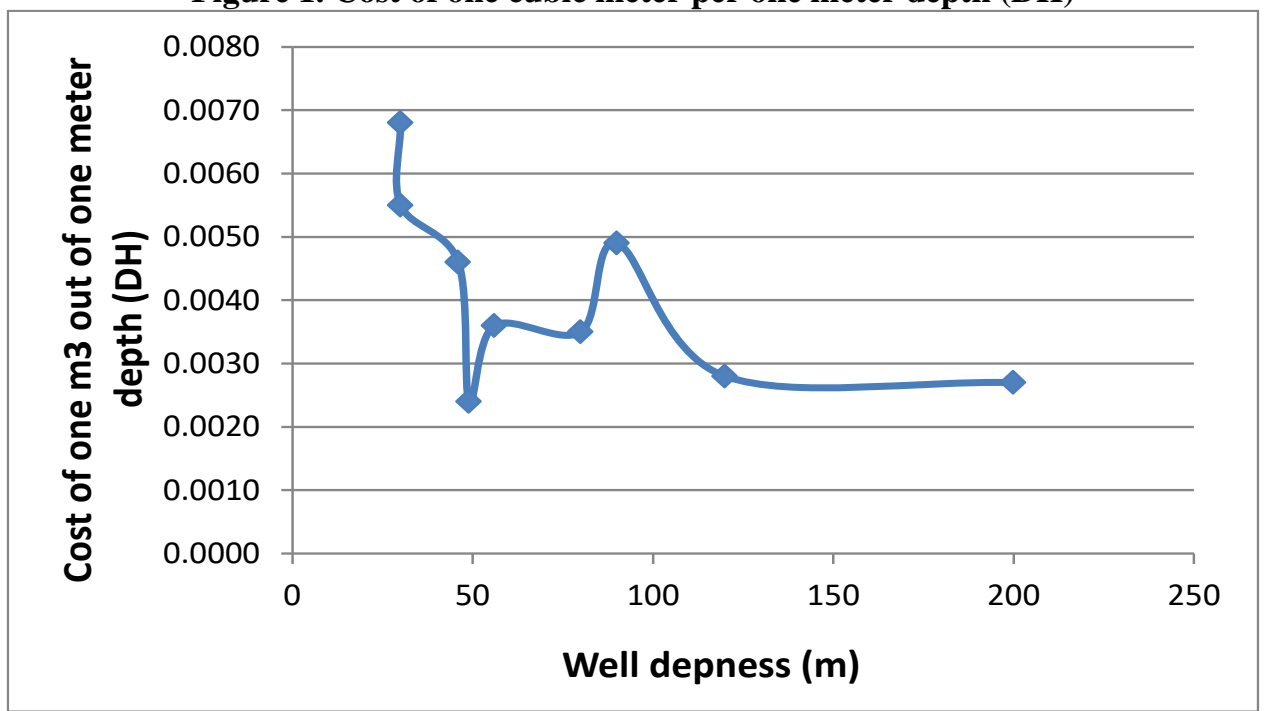

Source: Own elaboration based on data from interview with solar panel dealer in Rabat, Morocco.

To approximate the cost of pumping water using LPG and solar energy, we used the average cost of pumping of one cubic meter of water per one meter depth for wells with depths of 40-120 m (which is the most common in the two regions). The cost of pumping one cubic meter of groundwater using solar energy was 33.3\% cheaper than LPG in Sidi El Aidi, and 60.6\% cheaper in Fquih Ben Salah (Table 7). In other words, the average benefit of using solar energy instead of LPG in Sidi El Aidi and Fquih Ben Salah was one-third and almost two-thirds, respectively. However, these benefits have to be nuanced as solar energy requires a large initial investment (which can be difficult for farmers to afford), while LPG expenses are paid on an almost daily basis.

Table 7. Cost of pumping one cubic meter of groundwater

\begin{tabular}{l|c|c|c}
\hline & Liquefied gas $(\mathrm{DH})$ & Solar energy $(\mathrm{DH})$ & Difference $(\%)$ \\
\hline Sidi El Aidi & 0.30 & 0.20 & 33.3 \\
\hline Fquih Ben Salah & 0.33 & 0.13 & 60.6 \\
\hline
\end{tabular}

Source: Own elaboration based on solar panel survey.

\subsection{Net present value and subsidy to solar systems}

To more accurately evaluate solar energy as an option to LPG, we used NPV to determine the profitability of investing in solar energy. NPV is an appropriate tool to evaluate investment decisions when the objective of the farm is to maximize profits or wealth (Aw-Hassan, Rida, Telleria and Bruggeman, 2014). The advantage of using NPV is that it accounts for time value of money, which is reliable investment appraisal technique that discounts for future cash flows and accounts for rates of return. A well-known drawback of NPV is that it is based on estimated future cash flows, which can be difficult to predict. Therefore, we treated this drawback through sensitivity analysis that provided an estimation of the robustness of our results.

We assumed that the value added tax associated to purchasing of solar systems was included in the investment cost in the year the investment was made. The cost of the investment is included as cash flow in NPV. Most farmers in the two study sites did not have large farms, and hence for investment to be attractive it should comfortably cover the high risk of investment. Hence, we included uncertainty in the analysis by adjusting the discount rate upward to reflect additional risks inherent to agriculture plus a risk premium. As our survey did not include data on production costs and income (needed to estimate net cash flows), we used data generated under the 2010 Water Benchmarks Project ${ }^{5}$. This project surveyed 205 farmers in the Tadla region, which is in the same region as our survey was conducted. Data from

5 The Water Benchmarks Project, funded by the Arab Fund for Economic and Social Development and executed by ICARDA, has been validating and promoting low-cost technologies (such as supplemental irrigation and water harvesting) across West Asian and North African countries (including Morocco). 
this survey indicates that a representative farmer would have an average income, cost and production area profile as shown in Table 8.

Table 8. Income and cost structure of representative farmer

\begin{tabular}{l|c|c|c|c}
\hline Crop & Income $(\mathbf{D H})$ & Cost $(\mathbf{D H})$ & Net revenue (DH) & Production area (ha) \\
\hline Alfalfa & 4,125 & 1,276 & 2,849 & 1.25 \\
\hline Corn & 54,089 & 12,402 & 41,687 & 4.00 \\
\hline Olive tree & 52,500 & 2,501 & 49,999 & 2.50 \\
\hline Potato & 525 & 2,485 & $-1,960$ & 0.25 \\
\hline Onion & 1,300 & 1,125 & 175 & 0.50 \\
\hline Sesame & 3,125 & 1,088 & 2,038 & 0.50 \\
\hline Pepper & 2,875 & 8,392 & $-5,517$ & 0.50 \\
\hline Citrus & 1,200 & 1,500 & -300 & 1.50 \\
\hline Total agriculture & $\mathbf{1 1 9 , 7 3 9}$ & $\mathbf{3 0 , 7 6 9}$ & $\mathbf{8 8 , 9 7 0}$ & $\mathbf{1 1 . 0 0}$ \\
\hline
\end{tabular}

Source: Own elaboration based on Water Benchmarks project survey data (ICARDA, 2010).

Similarly to our survey, the average farmer had a production area of 11 ha, and diversified crop production aiming at reducing risks and widening consumption options. As Table 8 represents averages for one year, some crops had negative numbers, which conforms to the reality of farmers sometimes experiencing crop failures. Yet, positive results in most crops generally compensated for losses, rendering overall positive results at farm level. From the information obtained from the solar system provider (Table 4), we used the average investment cost of a solar system estimated at DH 221,177 (about US\$ 22,848), which was enough to irrigate 11 ha. From Table 8, we estimated that the annual net revenue from solar energy investment was DH 88,970 (about US\$ 767 per month). To cover for high risk inherent to agricultural activities we used a discount rate of $23 \%$ per annum (we set this high rate of return to discount net cash inflows from the investment). We used 20 years as the period of analysis considering that the solar panel dealer indicated that on average these systems comfortably last for 20 years. After this period, we assumed that the salvage value of the solar system was zero. With these data, we estimated the NPV of investment on solar energy would be DH 159,493 (US\$ $16,497)$, indicating that the investment would be profitable.

Our estimate of NPV is subject to uncertainty due to forecasts of future values. Therefore, we treated uncertainty through sensitivity analysis, which is the main technique used to test the robustness of results. To undertake sensitivity analysis, we identified that the main sources of uncertainty in the evaluation were income cash flow (critical parameter that determines the funding available each year) and the discount rate (determines attractiveness of the investment). The discount rate was set relatively high at $23 \%$ when considering the financial attractiveness of solar investment. This rate would be different for every farmer, but small-medium farmers would expect a relative high return for the investment. Therefore, we assumed that discount rate would increase to 30, 35, 40, 45 and 50\%, while the income cash flow would be reduced by 10, 20, 30, 40 and 50\% (Table 9). Our decision to use high rates of discount is justified by the fact that solar panel investments are unfamiliar to local farmers. They frequently imitate progressive farmers that have invested in a new technology, but in the areas under study there are no local farmers that have embarked into solar energy utilization. This brings uncertainty in regards to lack of experience that can bring about operating losses and failures out of the investment. The use of high discount rates can account for that risk.

Table 9. Sensitivity analysis, reductions in income and increases in discount rates (r)

\begin{tabular}{l|ccccc}
\hline Parameter & NPV1 & NPV2 & NPV3 & NPV4 & NPV5 \\
\hline Income reduction (\%) & 10 & 20 & 30 & 40 & 50 \\
New income (DH) & 107,765 & 95,791 & 83,817 & 71,843 & 59,869 \\
New net revenue (DH) & 76,996 & 65,023 & 53,049 & 41,075 & 29,101 \\
New NPV (DH) & 108,261 & 57,030 & 5,798 & $-45,434$ & $-96,665$ \\
\hline Change in r (\%) & 30 & 35 & 40 & 45 & 50 \\
New NPV (DH) & 73,830 & 32,395 & 983 & $-23,582$ & $-43,290$ \\
\hline
\end{tabular}

Source: Own elaboration based on Water Benchmarks project survey data (ICARDA, 2010).

Results suggested that the new NPV would stand reductions in income within the range of 10-30\%. Income reductions of $40 \%$ or more (i.e. NPV4 and NPV5) would make investment in solar energy unprofitable. Sensitivity analysis also showed that the new NPV coped with increases of discount rates of up to $40 \%$. Discount rates of $45 \%$ or more meant that investment in solar energy was not profitable. These results suggest that investing in solar energy would 
bring benefits, but risks associated with unexpected income reductions or substantial increases in discount rates could nullify profitability. As Narvarte, Lorenzo \& Aandam (2005) pointed out, large investments (such as solar panels) bring uncertainty and risks that might not be easily taken by farmers. The World Bank (2013) suggests that building some safeguards to investments would bring the flexibility farmers need to embark on large investments such as solar-powered energy systems. Such safeguards can take the form of subsidies, insurance on various elements of the business (such as crop failure or contingencies), disaster allowances or any other measure aimed at reducing inherent risk and uncertainty of the investment.

Generally, our estimates suggested that solar energy would be a cost-effective option for farmers willing to invest in solar panels. Solar energy used in irrigation has been successfully tested in other countries such as Jordan, India, Ethiopia and the United States (Aligah, 2011; Argaw et al., 2003; Bekele et al., 2009; Bhave 1994; and Chikaire et al., 2010) where solar systems became more attractive when governments provided financial and technical support to purchase them.

\subsection{Comparative analysis of $\mathrm{CO}_{2}$ emissions from $\mathrm{LPG}$ and diesel systems}

This section estimates the emission of carbon dioxide $\left(\mathrm{CO}_{2}\right)$ under the hypothesis that LPG and diesel were no longer used for pumping water, but replaced by solar-powered systems. Generally, $\mathrm{CO}_{2}$ is emitted whenever a fossil fuel (such as LPG or diesel) is ignited in a combustion process to transmit their energy to generate electricity for operating motors, pumps or machines. We followed Ould-Amrouchea, Rekiouab, and Hamidata (2010) combustion equations of LPG and diesel to estimate the amount of $\mathrm{CO}_{2}$ emitted by their respective utilization. According to the survey, 39 farmers used $51,040 \mathrm{~kg}$ of LPG in Sidi El Aidi, and 56 farmers in Fquih Ben Salah used 165,290 kg to pump groundwater (Table 10). Two farmers from Sidi El Aidi used 7,400 kg of diesel, while 16 farmers from Fquih Ben Salah used 72,797 kg, both to pump groundwater. For Sidi El Aidi, we estimated $\mathrm{CO}_{2}$ emissions from LPG to be $425 \mathrm{~kg}-\mathrm{CO}_{2} / \mathrm{ha}$ in 2013 , which is equivalent to emission levels of 19 standard passenger cars per year; similarly for Fquih Ben Salah, we estimated $477 \mathrm{~kg}$ $\mathrm{CO}_{2}$ /ha emission for LPG or equivalent to $\mathrm{CO}_{2}$ emissions of 61 standard passenger cars per year. For diesel in Sidi El Aidi, we estimated $\mathrm{CO}_{2}$ emissions of $1,397 \mathrm{~kg}-\mathrm{CO}_{2} /$ ha (equivalent to emissions of four standard passenger cars per year); while in Fquih Ben Salah, diesel emitted $972 \mathrm{~kg}-\mathrm{CO}_{2} /$ ha, equivalent to emissions of 44 standard passenger cars per year. As expected, emissions from diesel were much higher than those from utilization of LPG.

Table 10. Annual consumption of LPG and diesel and $\mathrm{CO}_{2}$ reduction

\begin{tabular}{l|c|c|c|c}
\hline \multirow{2}{*}{ Parameters } & \multicolumn{2}{|c}{ LPG } & \multicolumn{2}{c}{ Diesel } \\
\cline { 2 - 5 } & $\begin{array}{c}\text { Sidi El } \\
\text { Aidi }\end{array}$ & $\begin{array}{c}\text { Fquih Ben } \\
\text { Salah }\end{array}$ & $\begin{array}{c}\text { Sidi El } \\
\text { Aidi }\end{array}$ & $\begin{array}{c}\text { Fquih } \\
\text { Ben } \\
\text { Salah }\end{array}$ \\
\hline Annual consumption (kg/year) & 51,040 & 165,290 & 7,400 & 72,797 \\
\hline $\mathrm{CO}_{2}$ reduction per area (kg-CO $/$ /ha/year) & 425 & 477 & 1,397 & 972 \\
Equivalent to emission amount of passenger cars/year & 19 & 61 & 4 & 44 \\
\hline
\end{tabular}

Source: Own elaboration based on solar panel survey.

Estimations of these $\mathrm{CO}_{2}$ emissions correspond to our sample only. When we projected $\mathrm{CO}_{2}$ emissions for the total area equipped for irrigation in Morocco and assumed that only LPG was used to pump groundwater for irrigation, we estimated that LPG generated emissions of 676.4 million $\mathrm{kg}-\mathrm{CO}_{2} /$ year, equivalent to $\mathrm{CO}_{2}$ emissions generated by 153,006 passenger cars per year (representing $7.13 \%$ of all cars in Morocco). Similarly, if we assumed that only diesel was used to pump groundwater to irrigate the total area equipped for irrigation in Morocco, then $\mathrm{CO}_{2}$ emissions would be 1,457.9 million $\mathrm{kg}-\mathrm{CO}_{2} /$ year, equivalent to $\mathrm{CO}_{2}$ emissions of 329,773 passenger cars per year (or $15.37 \%$ of all cars in Morocco). These estimates present cases where either LPG or diesel is used for pumping groundwater. Usually a combination of both is used, but due to the lack of precise information concerning the shares of each, then assuming one or the other is an option. If a combination of both LPG and diesel was used, then the amount of $\mathrm{CO}_{2}$ emissions should be within $7.13-15.37 \%$ of the annual emissions of all passenger cars in Morocco.

In terms of energy saving, if we assumed that farmers discontinued using LPG and turned to solar energy, then we estimated that in Sidi El Aidi the energy from LPG saved would be 6,531 megajoules per hectare (MJ/ha) as Net Heating Value (NHV), which is equivalent to eight units of 60-W electric bulbs per year (Table 11). For Fquih Ben Salah this figure would be $18,976 \mathrm{MJ} / \mathrm{ha}$ as $\mathrm{NHV}$, equivalent to 24 units of $60-\mathrm{W}$ electric bulbs per year. If we assumed that farmers discontinue the use of diesel in favour of solar energy, then in Sidi El Aidi the energy from diesel saved would be 7,332 MJ/ha as NHV, equivalent to nine units of $60-\mathrm{W}$ electric bulbs per year; for Fquih Ben Salah the NHV would be $13,206 \mathrm{MJ} / \mathrm{ha}$, equivalent to 17 units of $60-\mathrm{W}$ bulbs per year. Again, these estimates correspond to our sample size.

If projections are made at national level, then switching from LPG to solar energy would mean a saving in fossil fuel of 10,389 terajoules/year (TJ/year) as NHV per total area equipped for irrigation, equivalent to 13 million $60-\mathrm{W}$ electric bulbs per year. In the case of farmers discontinuing use of diesel for solar energy, we estimated that energy saved would be $19,810 \mathrm{TJ} / \mathrm{ha}$ as $\mathrm{NHV}$, equivalent to 25 million $60-\mathrm{W}$ electric bulbs per year. As a combination of LPG and 
diesel is used in Morocco, we inferred that by using solar energy, the equivalent amount of energy saved should be within the range of $13-25$ million $60-\mathrm{W}$ electric bulbs per year.

Table 11. Annual consumption of LPG and diesel, $\mathrm{CO}_{2}$ reduction and heating value

\begin{tabular}{l|c|c|c|c}
\hline \multirow{2}{*}{ Indicator } & \multicolumn{2}{|c|}{ LPG } & \multicolumn{2}{c}{ Diesel } \\
\cline { 2 - 5 } & $\begin{array}{c}\text { Sidi El } \\
\text { Aidi }\end{array}$ & $\begin{array}{c}\text { Fquih Ben } \\
\text { Salah }\end{array}$ & $\begin{array}{c}\text { Sidi El } \\
\text { Aidi }\end{array}$ & $\begin{array}{c}\text { Fquih Ben } \\
\text { Salah }\end{array}$ \\
\hline Net Heating Value per Area, NHV (MJ/ha/year) & 6,531 & 18,976 & 7,332 & 13,206 \\
Equivalent to 60-W electric bulb (bulbs/year) & 8 & 24 & 9 & 17 \\
\hline \multicolumn{3}{c}{ Estimation at national level } & 10,389 & 19,810 \\
\hline Net Heating Value per total area equipped for irrigation, NHV (TJ/year) & 13 & 25 \\
Equivalent to 60-W electric bulb (million bulbs/year)
\end{tabular}

Source: Own elaboration based on solar panel survey.

Farmers, the environment and the government would gain by replacing LPG with solar energy. However, once the solar systems are installed, practically there is no electricity or fuel cost to pump groundwater, and thus no incentives to farmers to moderate water consumption, generating a strong risk of overexploitation and even depletion. Coupling solar systems with efficient irrigation methods, such as drip irrigation, is not enough as it does not guarantee that water is saved (FAO, 2018), or that farmers don't search for extra-income avenues such as selling water to neighbours.

In 1995 the Moroccan government released the Law of Water (Law No. 10-95), which was a major breakthrough in Moroccan water policy (Geosciences, 2020), and stablished three major objectives: a) Rationalizing water use by developing national and river basin plans; b) Providing universal access to water resource; and c) Reducing disparities between cities and villages and ensure water security across the country. In 2009 Morocco released the National Water Strategy (SNE) and the National Water Plan (PNE), which focussed on several actions to promote sustainability in water use, including regulations for: a) Construction of dams; b) Water transfers among regions; c) Use of non-conventional water resources (e.g. desalination of seawater, brackish water, and reuse of treated wastewater); d) Incentives for converting to water-saving technologies (e.g. drip irrigation and sprinkler irrigation); e) Preservation of groundwater resources through artificial recharge, and setting limits on how much groundwater can be pumped; and f) Reforestation.

Among all these regulations, the government has not made available a specific policy or regulation that introduces a groundwater meeting system (i.e. installation of water meters on wells to accurately measure withdrawals) for supervising groundwater abstraction. This system, frequently associated with a water costing approach per cubic meter abstracted, is reported to be one of the most effective mechanisms to monitor and to rationalize the use of groundwater (McCathran, Anderson, and Hermitte, 2015). Other options to monitor groundwater withdrawals should also be assessed, always aiming at providing appropriate government regulations and policies that ensure that groundwater is not overexploited, but on the contrary it is managed in a sustainable and rational manner. The cooperation of farmers is essential for this to happen. Raising awareness among farmers to accept groundwater monitoring and regulation systems would be needed.

\section{CONCLUSIONS AND RECOMMENDATIONS}

The main purpose of this research was to analyse the feasibility of solar energy as a primary power-source to pump irrigation water. We found that there is a trend to widespread use of LPG in pumping groundwater for irrigation. The reason for this is that the cost of pumping groundwater using diesel is twice that of using LPG (i.e. 0.67 and 0.30 $0.33 \mathrm{DH} / \mathrm{m}^{3}$, respectively). This change to LPG has been stimulated by the progressive reduction in the diesel subsidy that, with the LPG subsidy unchanged, makes diesel increasingly more expensive than LPG. Consistent with this finding, our survey showed that $87 \%$ of all surveyed farmers (112) had already switched to LPG in preference to diesel. Our simulations predicted that if LPG was used to irrigate $30 \%$ of private land in Morocco, then the impact on government would be a subsidy increase of 0.4 billion DH (about US\$ 41.3 million) per year, representing a $3.3 \%$ increase in subsidies provided to LPG in 2018. If LPG was used to irrigate $100 \%$ of private irrigated areas, then the LPG subsidy would grow by 1.33 billion DH (about US\$ 138 million) annually, representing $11 \%$ of the 2018 subsidy to LPG in Morocco.

If farmers decided to invest in solar energy, our estimates suggest that solar energy would be a more convenient option than LPG. We estimated that the cost of pumping one cubic meter of groundwater using solar energy was $33.3 \%$ cheaper than LPG in Sidi El Aidi, and 60.6\% cheaper in Fquih Ben Salah. In addition, NPV estimates suggested that investing in solar panels was profitable. However, the sensitivity analysis suggested that the large initial investment might not be easily taken by farmers, and therefore the government should consider providing some support to reduce the risk associated with such a large investment. Findings also suggest that if farmers eventually adopted solar energy, the 
government should not expect the LPG system to be completely abandoned because farmers will want to ensure that more than one energy option to secure groundwater is available.

Environmental evaluation of $\mathrm{CO}_{2}$ emissions from LPG and diesel suggests that diesel contaminates more than LPG. We estimated that the level of $\mathrm{CO}_{2}$ emission from LPG due to pumping groundwater is equivalent to the emissions that $7.13 \%$ of all passenger cars in Morocco generate in one year. In the case of diesel, we estimated that $\mathrm{CO}_{2}$ emissions from pumping groundwater would be equivalent to those generated by $15.37 \%$ of all Morocco's passenger cars per year. In general, our estimates suggested that use of LPG and diesel would generate $\mathrm{CO}_{2}$ emissions equivalent to those of 7.13-15.37\% of all passenger cars in Morocco in one year. Switching from LPG or diesel to solar energy would mean energy saving equivalent to 13-25 million 60-W electric bulbs per year, depending on the type of fuel replaced (i.e. LPG or diesel).

We consider that the government, farmers and the environment would gain by replacing LPG with solar energy. However, it is important to point out that once solar panels are installed, the cost of pumping groundwater is virtually zero. Farmers may be tempted to overuse irrigation water and to extend their irrigated areas, and consequently accelerate the depletion of groundwater. Therefore, the government needs to introduce policies and regulations, as essential requirement, to regulate the amount of groundwater pumped, and assess the possibility of costing groundwater to make it sustainable in the short and long term. This also needs farmer awareness raising to ensure acceptance of groundwater monitoring and regulation. These measures may be very challenging to implement, but they are needed to conserve groundwater resources.

\section{REFERENCES}

- Albertin, G., 2014. Subsidy Reform in MENA. Presentation at the 7th annual meeting of the MENA Senior Budget Officials held on 10-11 December 2014. http://www.oecd.org/gov/budgeting (accessed on 29 May, 2020).

- Aligah, M.A., 2011. Design of photovoltaic water pumping system and compare it with diesel powered pump. Jordan J. Mech. Ind. Eng. 5, 273-280.

- Argaw, N., Foster, R., \& Ellis, A., 2003. Renewable energy for water pumping application in rural villages. National Renewable Energy Laboratory, USA.

- Aw-Hassan A., Rida F., Telleria R. and Bruggeman A., 2014. The impact of food and agricultural policies on groundwater use in Syria. Journal of Hydrology 513 (2014) 204-215.

- Bekele, A.S. Lemperiere, P., \& Tulu, T., 2009. Pumps for small-scale irrigation. International Water Management Institute (IWMI), Supported through: Improving Productivity and Market Success (IPMS) of Ethiopian farmers project and International Livestock Research Institute (ILRI), Addis Ababa, Ethiopia.

- Bhave, A., 1994. Potential for solar water-pumping systems in India. Applied Energy 48, 197-200.

- $\quad$ Chikaire, J., Nnadi, F.N., Nwakwasi, R.N., Anyoha, N.O, Aja O.O., Onoh P.A., \& Nwachukwu C.A., 2010. Solar energy applications for agriculture. Journal of Agricultural and Veterinary Sciences 2, 58-62.

- FAO, 2015. AQUASTAT Profil de Pays - Maroc. http://www.fao.org/3/ca0203fr/CA0203FR.pdf (accessed on 12 June 2020).

- FAO, 2018. The benefits and risks of solar-powered irrigation - a global overview. Food and Agriculture Organization of the United Nations and Deutsche Gesellschaft für Internationale Zusammenarbeit. Hans Hartung. http://www.fao.org/3/i9047en/I9047EN.pdf (accessed on 12 April 2020).

- Geosciences, 2020. Moroccan Groundwater Resources and Evolution with Global Climate Changes. Geosciences 2020, 10, 81; doi:10.3390/geosciences10020081. Hssaisoune M., Bouchaou L., Sifeddine A., Bouimetarhan I., and Chehbouni A., https://www.mdpi.com/2076-3263/10/2/81/pdf (accessed on 21 May 2020)

- Hespress, 2019. PLF 2020 : Baisse observée de la compensation du gaz butane. Khadija Khettou. https://fr.hespress.com/102613-plf-2020-baisse-observee-de-la-compensation-du-gaz-butane.html (accessed on 11 June, 2020).

- ICARDA, 2010. Water Benchmarks Project. http://www.icarda.org/water-benchmarks-project (accessed on 11 April, 2020). 
- IISD, 2018. Swap: Reformer l'appui au gaz butane pour investir dans le solaire au Maroc. International Institute for Sustainable Development. Publié par l'Institut international du développement durable. https://www.iisd.org/sites/default/files/publications/swap-morocco-fr.pdf (accessed on 11 April, 2020).

- IISD, 2019. Fossil Fuel to Clean Energy Subsidy Swaps: How to pay for an energy revolution. Bridle R., Sharma s., Mostafa M. and Geddes A. International Institute for Sustainable Development. And Global Subsidies Initiative.

- IMF, 2014. Subsidy Reform in the Middle East and North Africa Recent Progress and Challenges Ahead. Sdralevich C., Sab R., Zouhar Y., and Albertin G. International Monetary Fund. http://www.imf.org/external/pubs/ft/dp/2014/1403mcd.pdf (accessed on 12 February, 2020).

- IMF, 2017. If Not Now, When? Energy Price Reform in Arab Countries. Annual Meeting of Arab Ministers of Finance. April 2017, Rabat, Morocco. International Monetary Fund. https://www.imf.org/en/Publications/Policy-Papers/Issues/2017/06/13/if-not-now-when-energy-price-reform-inarab-countries (accessed on 21 December, 2019).

- McCathran M., Anderson B., and Hermitte S., 2015. Groundwater Production Monitoring in the State of Texas. Technical Note 15-06. https://www.twdb.texas.gov/publications/reports/technical_notes/doc/TechnicalNote1506.pdf (accessed on 2 February, 2019)

- MEFRA, 2020. Ministère de L'économie, des Finances et de la Réforme de L'administration, Royaume du Maroc. https://www.finances.gov.ma/Publication/db/2020/rapport-compens-plf20-fr.pdf (accessed on 12 June, 2020).

- Narvarte L., Lorenzo E., \& Aandam, M., 2005. Lessons from a PV pumping programme in south Morocco. Prog. Photovolt. Res. Appl. 13:261-270.

- Ould-Amrouchea S., Rekiouab D., \& Hamidata A., 2010, Modeling photovoltaic water pumping systems and evaluation of their CO2 emissions mitigation potential. Applied Energy; 87(11):3451-9.

- World Bank, 2013. Implementing Energy Subsidy Reforms - Evidence from Developing Countries. International Bank for Reconstruction and Development. Maria Vagliasindi. https://openknowledge.worldbank.org/handle/10986/11965 (accessed on 9 April, 2020).

- World Bank, 2019. Créer des Marchés au Maroc une Deuxième Génération de Réformes : Stimuler la Croissance du Secteur Privé, la Création D'emplois et L'amélioration des Compétences Diagnostic du Secteur Privé. https://www.ifc.org/wps/wcm/connect/17d935af-349c-4c6f-93f5-5d85f0c16e39/201910-CPSD-MoroccoFR.pdf?MOD=AJPERES\&CVID=n48yfDT (accessed on 6 June, 2020). 